\title{
Social support from the perspective of adolescent victims of domestic violence
}

\author{
O APOIO SOCIAL SOB A ÓTICA DE ADOLESCENTES VÍTIMAS DE VIOLÊNCIA \\ DOMÉSTICA
}

\section{EL APOYO SOCIAL DESDE LA PERSPECTIVA DE LOS ADOLESCENTES VÍCTIMAS DE VIOLENCIA DOMÉSTICA}

\section{Diene Monique Carlos ${ }^{1}$, Maria das Graças Carvalho Ferriani², Michelly Rodrigues Esteves', Lygia Maria Pereira da Silva ${ }^{3}$, Liliana Scatena ${ }^{4}$}

\section{ABSTRACT}

Objective: Assess the understanding of adolescents regarding the social support received in situations of domestic violence. Method: A qualitative study with data collection carried out through focus groups with 17 adolescent victims of domestic violence, institutionally welcomed in Campinas-SP, and through semi-structured interviews with seven of these adolescents. Information was analyzed by content analysis, thematic modality. Results: Observing the thematic categories it was found that social support for the subjects came from the extended family, the community, the Guardianship Council, the interpersonal relationships established at the user embracement institution and from the religiosity/ spirituality. Conclusion: The mentioned sources of support deserve to be enhanced and expanded. With the current complexity of the morbidity and mortality profiles, especially in children and adolescents, the (re)signification and the (re)construction of health actions is imperative.

\section{DESCRIPTORS}

Social support

Adolescent

Domestic violence

Nursing

Adolescent health

\section{RESUMO}

Objetivo: Analisar a compreensão de adolescentes quanto ao apoio social recebido em situações de violência doméstica. Método: Pesquisa qualitativa cuja coleta de dados foi realizada por meio de grupos focais com 17 adolescentes que são vítimas de violência doméstica, acolhidos institucionalmente em Campinas-SP e de entrevistas semiestruturadas com sete destes adolescentes. Os dados foram analisados por meio da análise de conteúdo, modalidade temática. Resultados: Observando as categorias temáticas encontradas, revelase que o apoio social para os sujeitos foi proveniente da família extensa, da comunidade, do Conselho Tutelar, das relações interpessoais estabelecidas na instituição de acolhimento e da religiosidade/espiritualidade. Conclusão: As fontes de apoio citadas merecem ser potencializadas e ampliadas. Com a atual complexidade dos perfis de morbimortalidade, em especial de crianças e adolescentes, é urgente a (re) significação e a (re)construção das ações em saúde.

\section{DESCRITORES \\ Apoio social \\ Adolescente \\ Violência doméstica \\ Enfermagem \\ Saúde do adolescente}

\section{RESUMEN}

Objetivo: Analizar la comprensión de los adolescentes en relación al apoyo social en situaciones de violencia doméstica. Método: Investigación cualitativa, cuya recolección de datos se realizó a través de grupos focales con 17 adolescentes víctimas de violencia doméstica y acogidos institucionalmente en la ciudad de Campinas, SP, y entrevistas semi-estructuradas con 7 de ellos. Los datos fueron analizados utilizando el análisis de contenido, modalidad temática. Resultados: A través de las categorías temáticas encontradas, se revela que el apoyo social para los sujetos proviene de la familia extensa, de la comunidad, del Consejo Tutelar, de las relaciones interpersonales establecidas en la institución de acogida y de la religiosidad y espiritualidad. Conclusión: Se requiere potenciar y aumentar las fuentes de apoyo citadas. Con la actual complejidad de los perfiles de morbimortalidad, en especial de los niños y adolescentes, es urgente la resignificación y la reconstrucción de las acciones en salud.

DESCRIPTORES
Apoyo social
Adolescente
Violencia doméstica
Enfermería
Salud del adolescente

\footnotetext{
Doctorate Student, Postgraduate Program in Public Health Nursing, School of Nursing of Ribeirão Preto, Universidade de São Paulo, Ribeirão Preto, SP, Brazil. 2 Titular Professor, Department of Maternal-Child Nursing and Public Health, School of Nursing of Ribeirão Preto, Universidade de São Paulo, Ribeirão Preto, SP, Brazil. ${ }^{3}$ Adjunct Professor, Universidade de Pernambuco, Recife, PE, Brazil. ${ }^{4}$ Doctorate Student, Interunit PhD Program in Nursing, School of Nursing and Achool of Nursing of Ribeirão Preto, Universidade de São Paulo, Ribeirão Preto, SP, Brazil.
} 


\section{INTRODUCTION}

Violence is recognized as a serious public health problem in the contemporary world. Children and adolescents form the most vulnerable population groups to this abuse, especially by the imbalance in power relations with adults $^{(1)}$. Accidents and violence are configured as the primary cause of death involving children older than one year and adolescents aged up to 19 years ${ }^{(2)}$. Moreover, the consequences of violence are often not visible, but can last until adulthood, encompassing feelings of devaluation manifested by low self-esteem and destructive personal characteristics (antisocial and violent behavior) ${ }^{(1)}$.

The highest rates of violence occur within households $^{(2)}$. For purposes of conceptualizing violence among its various manifestations and classifications, the present study uses the term domestic violence that involves individuals transiting within the same house, with or without blood ties, and who have some level of affection or not ${ }^{(3)}$. In this context, individuals are related through aggressive actions to resolve conflicts and as an education strategy, which also includes the lack of basic care to children. For belonging to the private sphere, this may extend over a long period, making its identification difficult ${ }^{(1,3)}$.

The domestic environment is the one that can better protect or expose children and adolescents to violence. Given the omission with regard to the role of protection, and in cases of violence perpetuation in this environment, new kinds of support should be offered in order that individuals can tackle the adversities.

Social support is one of the protective factors for children and adolescents ${ }^{(4)}$. The scientific literature contains several definitions for this concept as theoretical frameworks and models of varied practice, with some similarities $^{(5-6)}$. In this study, this concept is understood as a process involving bonds of friendship and informational that establishes exchanges to meet needs of any kind, and results in emotional and behavioral positive effects, which facilitate coping with a crisis ${ }^{(7)}$. Several studies refer to the importance of social support for the health and quality of life of individuals throughout their life cycle ${ }^{(5-6,8-9)}$.

Social support has been the subject of several studies involving new perspectives and new practices, primarily related to the maternal-child health and of the elderly, and focused on the effective support arising from the community ${ }^{(5-6,8-9)}$. However, studies relating the concept of social support to domestic violence against children and adolescents are still embryonic and missing the point of view of subjects themselves victims of this phenomenon. Considering the particularities of the experience of domestic violence for adolescents, the importance of combining the concept of social support to this theme, as well as gaps in scientific knowledge about this relationship, bring up the question: Which help do adolescents perceive when they are victims of domestic violence? Thus, the aim of this study was to analyze the understanding of adolescents regarding the social support received in situations of domestic violence.

The concept of social support guiding the present research is appropriate to address the aspects experienced by adolescent victims of domestic violence, implying a closer understanding of the reality lived by them and of the supports offered. Such understanding will enable the construction of a comprehensive care directed to these subjects, providing a foundation for actions of health promotion and disease prevention.

\section{METHOD}

This study is based on a qualitative approach, the type of social strategic research oriented towards concrete and focal problems emerging of society, in which offering practical solutions to the raised problems is not necessarily part of the researcher's role ${ }^{(10)}$.

The study was carried out in Campinas-SP, which structures its network of care to child and adolescent victims of domestic violence through the Bureau of Citizenship, Welfare and Social Inclusion (Secretaria de Cidadania, Assistência e Inclusão Social), always aiming at an intersectoral work, run in partnership with other departments. The operation of this agency is divided mainly in basic and special protection networks. The first is through institutions that foster autonomy of families and has a more preventive nature. The area of special protection encompasses the institutions of user embracement and other equipment. It is focused on individualized care with interventions to reorganize the nuclear family, and is divided into actions of medium and high complexity. The institutional user embracement is considered an action of high complexity and carried out mostly by Non-Governmental Organizations (NGOs) co-financed by the Municipality of Campinas.

The field of study was one of the NGOs who welcome children and adolescents in situations of personal and social risk, including those victims of domestic violence, and referred by the Guardianship Council (Conselho Tutelar - CT) or the Court for Childhood and Youth (Vara da Infância e Juventude - VIJ). This NGO was chosen because it is directed to the reception of adolescents, subjects of this study. In 2009, the NGO received 176 individuals, among which 166 were teenagers.

The studied institution is structured in group homes where up to 16 people live. Generally, children and adolescents are organized in these homes by gender, age, and sibling groups. A social father or mother is responsible for male or female children and adolescents, respectively.

The study subjects were adolescents aged 12-18 years, in accordance with the age group established by the Statute for Child and Adolescent (Estatuto da Criança e do Adolescente $(E C A)^{(11)}$, victims of domestic violence, 
welcomed at the researched institution, and who were willing to participate in the study. The sample was defined by the criterion of data saturation, from the recurrence of the information ${ }^{(10)}$. The institutional user embracement service presented a list of 66 adolescents who met these criteria. Among these, were selected 17 adolescents; nine females and eight males, according to the greater availability to participate of data collection.

The techniques of focus groups and semi-structured interviews were chosen as strategies for data collection. The insertion of the researcher in the study field took place in February 2009, before the start of data collection, through technical support with training in disease prevention and health promotion for the institution professionals, in addition to individual nursing care and weekly informative groups with topics raised by the adolescents. These activities enabled approaching the empirical field and bonding with the children and adolescents. In September 2009, after completing this initial project, started the data collection by conducting two focus groups, presenting the following triggering questions: What is protection for you? Are there services and people who place themselves as protection and help you?

The groups were organized in a video room in the user embracement institution. The sessions lasted approximately 50 minutes and were recorded in MP4 system, with some observations noted by the researcher. All adolescents showed to be receptive and ready for the invitation of participating in the study, after clarification of the Terms of Consent and its signature. The letters ' $G F$ ' were used to represent the speeches of the focus groups, and the numbers I and II were used to represent the first and second focus groups, respectively.

At the end of the groups, the adolescents were invited to participate in semi-structured interviews, based on two guiding questions: Who are the people and services that help you in your daily life? Which people and services helped you when you were out of the group home? After the seventh interview, the data collection was aborted due to reaching data saturation in relation to the initial universe of $17 \mathrm{sub}$ jects. Interviews were also carried out in a room of the institution that ensured the privacy of teenagers. The sessions were recorded in an MP4 player and lasted approximately 45 minutes. Fictitious names chosen by the adolescents during the interviews were used to ensure their anonymity. The participants were four female teenagers and three males.

The study was reviewed by the Ethics Committee in Research of the School of Nursing of Ribeirão Preto of the Universidade de São Paulo - EERP/USP and approved under Protocol number 1080/2009. After this approval, an authorization was requested to the coordination service of the user embracement institution for collecting data on adolescents.

Data were analyzed from the framework of social support, according to the method of content analysis, thematic modality ${ }^{(12)}$. For implementation of this method, were established the following criteria: pre-analysis; exploration of the material; and treatment of results. For this analysis were established two analytic categories: breaking with the situation of domestic violence and protecting oneself from situations of domestic violence. These categories were developed after an initial comprehensive reading of the set of data: reports from focus groups, and interviews after full transcript. Both refer to the trajectory and experiences of adolescents who suffered domestic violence and problematize the significant support received throughout that course. From these principles came the following steps of analysis: identification of the central ideas (units of meaning) of each analytical category; comparisons between the various units of meaning, and organization and discussion of the categories presented in the following session.

\section{RESULTS}

The first focus group consisted of nine teenagers randomly selected from the list provided by the institution. Among them, four were male and five were female; three were aged 17 years, four were 16 years old and two were 15 years old. All of them were attending school when the group was formed.

The second group consisted of eight teenagers (four females and four males). One of them was aged 17 years, three were 16 years old, two were 15 years old and two were 13 years old. In this group, as in the previous one, all participants were attending school. Despite this fact, there was considerable disparity between the age and level of education of adolescents, because many of them were not attending school when living outside the institution.

Units of meaning emerged from the analysis of the data observed in the speeches, as presented in the two thematic categories described below.

\section{Breaking with the situation of domestic violence}

In this unit of meaning were addressed the reports of adolescents about the received social support that encouraged them to break with the situation of domestic violence and seek competent authorities to protect them.

Although domestic violence is maintained not only by family members, but also by other individuals transiting within the same home, the adolescents pointed their parents as responsible for the violence experienced, i.e., individuals belonging to the nuclear family. In these moments, the extended family such as grandparents and uncles, who often do not reside in the same house, were identified as support for these adolescents:

I had no support from my family, only from my Grandma (...) (Negro).

And the person who stuck with me all this time was my uncle (...) (Céu).
Social support from the perspective of adolescen victims of domestic violence Carlos DM, Ferriani MGC, Esteves MR, Silva LMP, Scatena L 
According to the statements, it seems that the neighborhood and friends acted as an important support to break the cycle of domestic violence, in particular by encouraging to report the situation:

There was a neighbor that lived at the back of my house and that was my age, and there lived only her and her mother, you know... Then, when my Father hit me, she gave me the idea to report him... (Céu).

The school is an institution of great importance, not only in the aspect of education, but also in the protection of children and adolescents. However, in the situation of violence, it is difficult for the school to assume the roles assigned to it. A teenager showed a relationship with this institution and acknowledged the support of a teacher to denounce the act of violence:

It was like... I used to show up at school with bruises, for

a long time l've been showing up bruised there, and the teacher used to say, you know, that I had to go to the Guardianship Council, but that she couldn't take me... (Mary).

The equipment of the Bureau of Social Welfare distributed around the municipality, such as community centers, service centers, projects aimed at teenagers and transient shelter services (Casas de Passagem) were also highlighted as strategic points of help for these adolescents:

Out there was the social worker named S., one of the guys that looked after the boys that were there [in the transient shelter], and another woman (Negro).

The Guardianship Council - CT has been recognized by the community as an important agency for the full protection of childhood and adolescence. This fact appears in the speech of adolescents who associate stopping a violent situation to the intervention of such agency:

Out there, I think what helped us was only the Council.. (GF II).

\section{Protecting oneself from the situation of domestic violence}

After the denouncement and acknowledgement of the situation of domestic violence experienced by adolescents, one of the interventions was their institutional embracement. Some teens had already passed through other services and were referred to the user embracement institution afterwards.

In this context, some professionals have emerged as support. Social fathers and mothers were cited as people with whom the teenagers established a relationship of trust and security:

When I did something wrong, they [social mothers] sat and talked (...) And I talked, and they showed me I could count on them... (Jaci).

Besides social fathers and mothers who worked directly with the teenagers, other professionals of the institution, as laundry service providers, technical management and monitors, also established relationships of help and care with the subjects of this study:

Like, when I'm sad the only person that comes to me and understands me is Auntie N. (...) she stays with me until the anger goes away... (Flor).

Teenagers also refer to God and the figure of the shepherd as important sources of support; it is noteworthy that the studied institution had bonds with a protestant religious entity.

The pastor, it's like, he gives me more security, also as a counselor because if I have something to tell him, I'm sure it's gonna be just between me, him and God (Negro).

Hey, it's all good ... except for the part of God, because primarily it is God... (Flor).

According to the adolescents, the institution offered them courses of formal and vocational education; they associated this fact with the preparation and creation of new expectations for the future. In these new perspectives, they found strategies to rebuild their lives and help their families:

Being somebody in life... having everything, a job, completed studies, having a family... (Flor).

I told her [mother] that I will study, be a musician and help her a lot... (Pincel).

\section{DISCUSSION}

The interpersonal relationships usually appear as promoters of people's adaptability in the provision of social support: emotional, instrumental and informational. The emotional support is by talking and establishing emotional relationships between people. The instrumental support refers to actions or materials offered to help in everyday tasks. The informational support relates to the available guidance and information about community resources ${ }^{(13)}$. It was revealed that adolescents first accessed the emotional support, and because of the specificities of the phenomenon of domestic violence, later on they were available to receive other types of social support.

Social support may also be considered formal (coming from the state or institutions) and informal (provided by the community and family) ${ }^{(13)}$. The literature corroborates the findings of this study when demonstrating that, in situations of vulnerability, the nuclear family is usually replaced by the extended family or the community that minimally ensures the survival of children and adolescents without legal intervention, through informal support ${ }^{(14-15)}$.

The community, more specifically the neighborhood and friends, has showed to be an important source of emotional and informational social support to adolescents. In a study examining the relationship between 
socio-contextual variables and work of children and adolescents ${ }^{(16)}$, the results showed the association of absence of social support from the community with the presence of work in this population. The literature also indicated that evaluating a neighborhood as non-supportive or distant is a risk factor for suicidal ideation of individuals ${ }^{(17)}$. It is noteworthy that community ties are recognized as valuable resources for reducing social exclusion and promoting adequate supply and access to public health services, social welfare, culture and education. Care to children and adolescents becomes a less isolated experience when the community is co-responsible for it, with more guidance and positive support ${ }^{(16)}$.

Despite occupying a privileged place in the lives of children and adolescents, the school does not assume its role as a protective institution of childhood and adolescence in full. A study on school integration of child and adolescent victims of domestic violence observed that the denouncement of suspected cases of violence is not stimulated by the coordination of these institutions; teachers feel intimidated because of the posture of those hierarchically superior to them ${ }^{(18)}$. These data corroborate studies on the role of health professionals facing domestic violence against children and adolescents. There is fear and difficulty in dealing with a problem of such complexity, because violence has several social determinants focused not only on the biological and concrete aspects, but also in other public health problems. Such social determinants stand as barriers to effective actions related to the management of these situations ${ }^{(19-20)}$.

From the speeches, it is understood that some services are placed at strategic locations to access children and adolescents, and often through instrumental social support, allowing possible references for these subjects and, from that point, providing them with new perspectives beyond suffering. The literature demonstrates that services need to be organized in actions integrating many social segments, formal or informal. And also reinforces the need to structure the work in networks of care and support to violence. In this context, nurses can develop strategies for adolescents involved in domestic violence and their families, knowing and accessing these networks through education and health care that promote autonomy and freedom for these individuals ${ }^{(8,21)}$. Primary prevention and health promotion of these individuals and their families; the awareness and recognition of the problem by professionals as inherent to the health sector; and coping with situations of violence by constructing interdisciplinary, interinstitutional and intersectoral interventions are the nursing category possibilities of approaching and appropriating of this debate(18-20).

Teenagers also refer to the Guardianship Council as an important source of informational and formal social support. It is important to emphasize that this institution is seen as significant for the population, because it is perceived as the main protection service to children and adolescents, which demonstrates the effective functioning of its structure in the care network and is a support that people actually have ${ }^{(22)}$.

In a study that analyzed the risk and protection factors in the care network for child and adolescent victims of sexual violence ${ }^{(4)}$, the Guardianship Council emerged as the most searched agency for denouncements and later follow-up of cases. Even though it is the main body for the protection of children and adolescents legitimized by the population, the literature brings several limitations of this agency. For example, cases of domestic violence against children and adolescents referred to the Guardianship Council are not followed-up in the long term, and the professionals involved in the assistance to this population feel a discredit or a prioritization of severe and immediate punitive actions ${ }^{(19-20)}$. This lack of monitoring the cases causes damages to the interventions of the Public Ministry, Court for Childhood and Youth, among other institutions ${ }^{(4)}$.

After investigating the situation of domestic violence, one of the interventions made by the Guardianship Council or the Court for Childhood and Youth was the institutional embracement of adolescents. In this environment, which must be exceptional and temporary ${ }^{(11)}$, the subjects highlighted the emotional social support received by the employees that interact directly or indirectly with them. The literature shows that the quality of the physical environment and the provided care are crucial to the development of children and adolescents welcomed institutionally, since they represent the nearest source of social support ${ }^{(23-24)}$

The context of institutional user embracement tries to reproduce the parental relationships, and caregivers may mediate fundamental aspects of the psychosocial development of children and adolescents, such as cognition, language and emotion. Human relations and the way employees establish a bonding with the welcomed population are important components in the evaluation of these institutions; the legislation advises that institutional user embracement should be permeated with safe and stable emotional relationships ${ }^{(23-25)}$.

In addition to the aforementioned types of support, some authors consider the religious/spiritual support too. Although used together, the concepts of religiosity and spirituality are different. In this study, the meaning of religiosity includes spirituality in a range of beliefs, customs and specific practices. Spirituality, on its turn, is an individualized phenomenon that may or may not follow the devotion to a transcendental being ${ }^{(26-27)}$. Religiosity and spirituality have been shown to be important coping and support strategies in several situations throughout the life cycle. In a study on religious experiences and spiritual practices in the different age groups, including throughout the aging process, it was found that such experiences
Social support from the perspective of adolescent victims of domestic violence Carlos DM, Ferriani MGC, Esteves MR, Silva LMP, Scatena L 
are essential to the well-being and have a positive impact on physical and mental health ${ }^{(28)}$. A study aimed at understanding the experience of illness for families of children with cystic fibrosis was corroborated; the authors report that religion, taken as a source of support, is a sociocultural conception apprehended in the family and social context in which children and adolescents are inserted. In this respect, the adopted doctrine is not the most significant, but the support offered by the religion ${ }^{(29)}$.

Finally, it was found that the institution provided instrumental support to adolescents through basic and vocational education. The service contributes to the development of adolescents by providing and promoting activities that bring educational and social adjustment, besides allowing to draft projects for the future life ${ }^{(24)}$. In this support, the teenagers found strategies to approach their families and demonstrate their need to feel they belonged to the nuclear family again ${ }^{(30)}$. This question is grounded by the recent overhaul of legislation aimed at children and adolescents institutionally welcomed. The family and community common living is strengthened as the main guideline for the care of this population and their families, but also represents a challenge ${ }^{(25)}$.

\section{CONCLUSION}

The adolescent victims of domestic violence accessed significant, informal, emotional and social sources of support, such as extended family and community, which led them to break with the violence situation experienced in their homes. Subsequently reinforced by the informational social support received by the community, they resorted to formal services, namely: territorialized social services and the Guardianship Council that through legal interventions broke the cycle of violence.

\section{REFERENCES}

1. Abranches CD, Assis SG. A (in)visibilidade da violência psicológica na infância e adolescência no contexto familiar. Cad Saúde Pública [Internet]. 2011 [citado 2012 jan. 20];27(5):843-54. Disponível em: http://www.scielosp.org/pdf/csp/v27n5/03.pdf

2. Brasil. Ministério da Saúde. Impacto da violência na saúde das crianças e adolescentes: prevenção de violências e promoção da cultura de paz [Internet]. Brasília; 2008 [citado 2012 jan. 20]. Disponível em: http://www.aads.org.br/arquivos/afccartilha.pdf

3. Brasil. Ministério da Saúde; Secretaria de Atenção à Saúde, Departamento de Ações Programáticas e Estratégicas. Linha de cuidado para a atenção integral à saúde de crianças, adolescentes e suas famílias em situação de violências: orientação para gestores e profissionais de saúde. Brasília; 2010.
One of the interventions to protect adolescents against the violence suffered was their institutional embracement. In this space, the subjects considered the emotional social support received by the employees and the religious/spiritual support as significant to face the experienced situation. New possibilities and prospects for the future and the (re) construction of family life emerged through instrumental social support provided by the institution of embracement.

This study has limitations because its results cannot be generalized due to the particularities of the involved subjects, but it presents important sources of social support for adolescent victims of domestic violence, which deserve to be enhanced and expanded.

With the current change and complexity of the morbidity and mortality profiles, especially of children and adolescents, the (re) signification and the (re) construction of health actions is imperative. Nurses, due to the legitimate and privileged role played in the healthcare team, should present themselves as protagonists and multipliers of this debate by transforming the practices through continuing education of professionals as well as transforming health services in sources of social support and effective components of a safety net for children and adolescents. Moreover, nurses can assist in building strategies for the promotion of the family and community living of this population, as well as actions with institutions of embracement and its professionals to enhance the sources of support in this context.

It is recommended the development of future studies on the institutional bonding in the care to families involved in domestic violence against children and adolescents from the perspective of intersectionality, as well as interventions of the health sector in this area, focused on health promotion and disease prevention.

4. Habigzang LF, Azevedo GA, Koller SH, Machado PX. Fatores de risco e de proteção na rede de atendimento a crianças e adolescentes vítimas de violência sexual. Psicol Reflex Crit [Internet]. 2006 [citado 2012 jan. 20];19(3):379-86. Disponível em: http://www.scielo.br/pdf/prc/v19n3/a06v19n3.pdf

5. Ferreira MB, Nunes MR, Reis GC, Morraye MA, Rocha SMM. Social support, socioeconomic and clinical risk: comparison between to neighborhoods in a Brazilian upcountry town. Rev Esc Enferm USP [Internet]. 2012 [cited 2013 June 03];46(4):822-8. Available from: http://www.scielo.br/pdf/reeusp/v46n4/06.pdf

6. Faquinello P, Marcon SS. Friends and neighbors: an active social network for adult and elderly hypertensive individuals. Rev Esc Enferm USP [Internet]. 2011 [cited 2012 Jan 20];45(6):1345-52. Available from: http://www.scielo.br/pdf/ reeusp/v45n6/en_v45n6a10.pdf 
7. Pedro ICS, Rocha SMM, Nascimento LC. Social support and social network in family nursing: reviewing concepts. Rev Latino Am Enferm [Internet]. 2008 [cited 2012 Jan 11];16(2):324-7. Available from: http://www.scielo.br/pdf/rlae/v16n2/24.pdf

8. Alexandre AMC, Labronici LM, Maftum MA, Mazza VA. Map of the family social support network for the promotion of child development. Rev Esc Enferm USP. 2012;46(2):272-9.

9. Brito TRP, Costa RS, Pavarini SCl. The elderly with cognitive alterations in the context of poverty: a study of the social support network. Rev Esc Enferm USP [Internet]. 2012 [cited 2013 June 03];46(4): 906-13. Available from: http://www.scielo.br/pdf/reeusp/v46n4/en_18.pdf

10. Minayo MCS. O desafio do conhecimento: pesquisa qualitativa em saúde. 11ạ ed. São Paulo: Hucitec; 2008.

11. Brasil. Lei n. 8.069, de 13 de julho de 1990. Estatuto da Criança e do Adolescente. Atualizado em novembro de 2003 em conformidade com a Lei no 10.764, de 12 de novembro de 2003, que altera a Lei no 8.069, de 13 de julho de 1990. Brasília: Senado; 1990.

12. Bardin L. Análise de conteúdo. Lisboa: Edições 70; 1977.

13. Sousa Al, Silver LD, Griep RH. Social support among elderly women in a low income area in the municipality of Rio de Janeiro. Acta Paul Enferm [Internet]. 2010 [cited 2012 Jan 11]; 23(5):625-31. Available from: http://www.scielo.br/ pdf/ape/v23n5/en_07.pdf

14. Gontijo DT, Medeiros M. Crianças e adolescentes em situação de rua: contribuições para a compreensão dos processos de vulnerabilidade e desfiliação social. Ciênc Saúde Coletiva [Internet]. 2009 [citado 2012 jan. 11];14(2):467-75. Disponível em: http://www.scielo.br/pdf/csc/v14n2/a15v14n2.pdf

15. Sarti CA, organizadora. A família como espelho: um estudo sobre a moral dos pobres. 7ạ ed. São Paulo: Cortez; 2011.

16. Santana VS, Itaparica MS. Social contextual factors contributing to child and adolescent labor: an ecological analysis. Rev Saúde Pública [Internet]. 2011 [cited 2012 Jan 20];45(4): 676-84. Available from: http://www.scielo.br/pdf/rsp/v45n4/2445.pdf

17. Silva VF, Oliveira HB, Botega NJ, Marín-León L, Barros MBA, Dalgalarrondo $P$. Fatores associados à ideação suicida na comunidade: um estudo de caso-controle. Cad Saúde Pública [Internet]. 2006 [cited 2012 Feb 29];22(9):1835-43. Disponível em: http://www.scielo.br/pdf/csp/v22n9/07.pdf

18. Carlos DM, Ferriani MGC, Silva MAI, Arone KMB. A reintegração de crianças e adolescentes institucionalizados vítimas de violência doméstica no espaço escolar. Rev Eletr Enferm [Internet]. 2008 [citado 2011 jun. 04];10(2):31020. Disponível em: http://www.fen.ufg.br/revista/v10/n2/ v10n2a03.htm
19. Nunes CB, Sarti CA, Ohara CVS. Health care professionals' approaches to address family violence against children and teenagers. Acta Paul Enferm [Internet]. 2009 [cited 2011 June 04];22(n.spe): 903-8. Available from: http://www.scielo.br/pdf/ape/v22nspe/en_12.pdf

20. Martins CBG, Melo Jorge MHP. Outcome of the violence against child and delivered to the judicial power. Acta Paul Enferm [Internet]. 2009 [cited 2011 June 04]; 22(6):800-7. Available from: http://www.scielo.br/pdf/ape/v22n6/en_ a12v22n6.pdf

21. Apostólico MR, Hino P, Egry EY. Possibilities for addressing child abuse in systematized nursing consultations. Rev Esc Enferm USP [Internet]. 2013 [cited 2014 Jan 31];47(2):3207. Available from: http://www.scielo.br/pdf/reeusp/v47n2/ en_07.pdf

22. Poletto M, Koller SH. Contextos ecológicos: promotores de resiliência, fatores de risco e de proteção. Estud Psicol (Campinas) [Internet]. 2008 [cited 2011 jun. 04];24(3):40516. Disponível em: http://www.scielo.br/pdf/estpsi/v25n3/ a09v25n3.pdf

23. Siqueira AC, Dell'Aglio DD. O impacto da institucionalização na infância e na adolescência: uma revisão de literatura. Psicol Soc. 2006;18(1):71-80.

24. More CLOO, Sperancetta A. Práticas de pais sociais em instituições de acolhimento de crianças e adolescentes. Psicol Soc. 2010;22(3):519-28.

25. Brasil. Lei n. 12.010, de 3 de agosto de 2009. Dispõe sobre adoção; altera as Leis n. 8.069, de 13 de julho de 1990 - Estatuto da Criança e do Adolescente, n. 8.560, de 29 de dezembro de 1992; revoga dispositivos da Lei n. 10.406, de 10 de janeiro de 2002 - Código Civil, e da Consolidação das Leis do Trabalho - CLT, aprovada pelo Decreto-Lei n. 5.452, de 10 de maio de 1943; e dá outras providências [Internet]. Brasília; 2009. Disponível em: http://www.planalto.gov.br/ ccivil_03/_ato2007-2010/2009/lei//12010.htm

26. Pillon SC, Santos MA, Goncalves AMS, Araújo KM. Alcohol use and spirituality among nursing students. Rev Esc Enferm USP [Internet]. 2011 [cited 2012 Jan 20];45(1):100-7. Available from: http://www.scielo.br/pdf/reeusp/v45n1/en_14.pdf

27. Cook $\mathrm{CCH}$. Addiction and spirituality. Addiction. 2004;99(5):539-51.

28. Valcanti CC, Chaves ECL, Mesquita AC, Nogueira DA, Carvalho EC. Religious/spiritual coping in people with chronic kidney disease undergoing hemodialysis. Rev Esc Enferm USP [Internet]. 2012 [cited 2013 June 03];46(4):838-45. Available from: http://www.scielo.br/pdf/reeusp/v46n4/en_08.pdf
Social support from the perspective of adolescent victims of domestic violence Carlos DM, Ferriani MGC, Esteves MR, Silva LMP, Scatena L 
29. Pizzignacco TP, Mello DF, Lima RG. The experience of disease in cystic fibrosis: the paths to comprehensive care. Rev Esc Enferm USP [Internet]. 2011 [cited 2013 June 03];45(3):63844. Available from: http://www.scielo.br/pdf/reeusp/ v45n3/en_v45n3a13.pdf
30. Martins CS, Ferriani MGC, Silva MAI, Zahr NR, Arone KMB, Roque EMST. Family dynamics from the perspective of parents and children involved in domestic violence against children and adolescents. Rev Latino Am Enferm [Internet]. 2007 [cited 2012 Jan 12]; 15(5):889-94. Available from: http://www.scielo.br/pdf/rlae/v15n5/v15n5a01.pdf 